\title{
Sectarianism in Iraq: the role of the coalition provisional authority
}

DOI:

10.1080/17539153.2018.1487178

\section{Document Version}

Accepted author manuscript

Link to publication record in Manchester Research Explorer

\section{Citation for published version (APA):}

Jacoby, T., \& Neggaz, N. (2018). Sectarianism in Iraq: the role of the coalition provisional authority. Critical Studies on Terrorism. https://doi.org/10.1080/17539153.2018.1487178

\section{Published in:}

Critical Studies on Terrorism

\section{Citing this paper}

Please note that where the full-text provided on Manchester Research Explorer is the Author Accepted Manuscript or Proof version this may differ from the final Published version. If citing, it is advised that you check and use the publisher's definitive version.

\section{General rights}

Copyright and moral rights for the publications made accessible in the Research Explorer are retained by the authors and/or other copyright owners and it is a condition of accessing publications that users recognise and abide by the legal requirements associated with these rights.

\section{Takedown policy}

If you believe that this document breaches copyright please refer to the University of Manchester's Takedown Procedures [http://man.ac.uk/04Y6Bo] or contact uml.scholarlycommunications@manchester.ac.uk providing relevant details, so we can investigate your claim.

\section{OPEN ACCESS}




\title{
Sectarianism in Iraq: The Role of the Coalition Provisional Authority
}

\author{
Prof. Tim Jacoby, Global Development Institute, \\ University of Manchester \\ Dr. Nassima Neggaz, School of History, Archaeology and Religion, \\ Cardiff University
}

\begin{abstract}
This article challenges recent analyses on sectarianism and Sunni-Shi'a conflict in Iraq by examining the political and economic factors that have underpinned the rising levels of internecine violence that have become apparent since 2003. Rather than rooted in 'ancient hatreds', these dynamics are, we argue, the outcome of a series of decisions and social transformations imposed on the Iraqi state in the immediate aftermath of the invasion - namely the format of the constitution, counter-insurgency policy, the establishment of a new media sector and the social effects of the Coalition's economic reorganisation.
\end{abstract}

\section{Keywords}

Iraq, Islam, Sunni-Shici conflict, culturalism, sectarianism, violence, civil war. 


\title{
Sectarianism in Iraq: The Role of the Coalition Provisional Authority
}

\author{
'During the time of the CPA, sectarian violence was almost unknown. We confirmed \\ fewer than 100 sectarian killings in the 14 months we were there'. \\ Paul Bremer (CPA Administrator 2003-2004) ${ }^{1}$
}

'We were ethnically cleansing.... you are killed according to identity'.

Abu Kemael (Mehdi Army member, 2005-2006) ${ }^{2}$

\section{Introduction}

As Eric Davis has noted, 'the problem with much Western analysis of Iraqi politics is the use of conceptual prisms that employ simplistic and flawed conceptions of ethnicity and religion'. Nowhere is this more apparent than in analyses of the country's violence patterns - particularly the shift in focus away from Coalition forces and towards civilian targets. ${ }^{3}$ Here, Davis continues, 'the key task is not to identify the existence of sectarian feelings, but to explain why, at a particular point in time, such feelings are translated into violent behaviour (Davis 2007, p. 3 (emphases in original)). With this in mind, we focus on the role of the political institutions which emerged following the invasion of 2003. In many cases, these are 'simply viewed as faithful reflections of cultural cleavages or as instruments to manage situations that are considered "givens", but we argue that the administrative structures and policy decisions established and pursued by the Coalition Provisional Authority (CPA) and its appointees provided the basis for the communal nature of much of the violence that has emerged since the invasion (Lecours 2000, p. 522).

The apparent 'sectarianisation' of society that has taken place is, in other words, not an inevitable outcome of the past, but rather actively produced and institutionalized by the occupying Coalition and its comprador regime. As Max Weiss puts it, 'states, societies, institutions, and communities become sectarian in unique ways, by diverse means, through processes that must be historically contextualized' (2010, p. 16). In Iraq, these means have been, we argue, fourfold - the 
use of supposed confessional identities as a basis for a "representative" constitution, the nascent state's counter-insurgency policies, the politicisation of a new media sector and the uneven impact of economic restructuring. Sectarian violence principally emerged in response to these contingent social changes, not - we shall contend - as a result of the country's pre-existing confessional peculiarities. Most fruitfully seen as an organisational principle, rather than a primordial urge, identity thus, we suggest, has operated in Iraq 'more as ordering device than as an impelling force' (Mueller 2000, p. 62).

\section{Culturalism and Violence}

The ferocious, and apparently wanton, character of civil wars has long led some to conclude that many are most profitably explained by ancient and insurmountable cultural differences. The human tendency to form exclusive, potent networks of attachment - or lack of therein - was, for Tönnies, Cooley and other pioneers of sociology, the key distinction between rationalist and individualist modernity and the 'primary group' structure of the Gemeinschaft. Believed by sociobiologists to be 'controlled primarily by the values, norms, or duties imposed by the sociocultural structure... distantly related to the basic propensities of individuals on which natural selection operated' (Hinde 1993, p. 49), this emphasis on the primordial roots of shared identity has been used, in its broadest form, to account for the social structures of developing countries, as well as anti-modern digressions within Western states (see Shils on Nazism, for instance (1957)). These are deemed especially potent where they overlap with religious affiliation and the 'powerful, pervasive, and long-lasting moods and motivations' it generates (Geertz 1973, p. 90). During the 1990s, amid a spate of particularly vicious civil wars, 'ancient hatreds' were again used to account for the apparently divisive role of faith and ethnicity in non-Western politics (Mueller 2000). The result, Steven David, concludes, is that, while 'West European countries have assimilated the social ideas and attitudes of peace', elsewhere others continue to maintain 'ideologically driven religious, ethnic, and political hatreds' (1992, p. 138).

While the grand canvass of Huntington's incompatible civilisations may have offered the broadest application of such thinking, the most widely cited case study has been the war in Yugoslavia. Here, a combination of ethnic and religious difference was adjudged so immutably volatile by writers such as Kaplan (1993a) and Ajami (1993) as to convince President Clinton 
that, firstly, intervention would be futile and, secondly, that any long-term future would inevitably involve territorial fragmentation (Kaufman, 1999). Convinced by observations, such as the former's claim that 'the Balkans are truly foreign... a cauldron of history... created by the collapse of the multinational Hapsburg and Ottoman empires', policy makers largely ignored local analysts' repeated emphasis of contemporary political dynamics not so very different from social problems further west (Kaplan 1993b). As Patrick Finney puts it, 'numerous external commentators accepted the claims of nationalist demagogues at face value and consequently represented these wars as historically determined, almost natural phenomena in a region inhabited by exotic primitives in thrall to primordial hatreds and a cyclical history of vicious blood-letting' (2010, p. 343).

Today, much of what has been written and said about the conflagration in Iraq is little different. There, and in neighbouring Syria, it is said, in a discourse strikingly similar to commentaries on the role of Tito in Yugoslavia, that the Hussein and Assad families kept a lid on the ancient hatreds that have always existed between Shi'a and Sunnis through Ba'athism's repressive patrimonialism. ${ }^{4}$ As soon as people had the opportunity - via a combination of rebellion and external intervention - to express their identities more freely, then, the narrative goes, a return to confessional chauvinism becomes all but inevitable. As Tony Blair put it, 'once the regime changes, then out come pouring all the tensions - tribal, ethnic and of course above all religious; ...the sectarian divisions become even more acute and the result is the mess we see all over the region' (2014). The bloodshed which followed the 'liberation' of Iraq was thus not a political response (or even an attempt to retake the refineries), but part of a broader, age-old war between two primordial and immutably incompatible blocs who incomprehensibly and permanently fell out long before the West discovered that God had put its oil under their sand (to paraphrase a popular bumper-sticker).

Resistance to the occupation was, for Washington insiders such as Soner Çağaptay, a result of a 'problem within Islam' - specifically Sunni Arabs' sectarian inability to accept a democratic, Shi'amajority government (2004). Inadvertently 'embroiled in a 1400 year old dispute', the West's failure 'to admit the fact that Islam is essentially two religions' organised around unremitting hatred is, for many, the key reason for the gradual fragmentation of Iraqi society (Lawrence 2015). The reasons for this must apparently 'be traced back', defence analysts at the House of 
Commons conclude, to the intrinsic cultural incommensurability of the region's component parts which, in an echo of 1990s thinking on the Balkans, render the country 'fundamentally fractious (and perhaps fundamentally not viable)' (Smith, Brook-Holland and Page 2014). Its final implosion in 2014 is therefore presented as conclusive evidence that Iraq has never been, and could never be, a functional unitary state (Burleigh 2014). It is perhaps no surprise then to see that many senior voices within the Coalition issued calls for a partition relatively soon after the scale of the insurrection became obvious. 'The idea, as in Bosnia', wrote Joseph Biden and Leslie Gelb in May 2006, is to give 'each ethno-religious group - Kurd, Sunni Arab and Shiite Arab room to run its own affairs....[by] establish[ing] three largely autonomous regions' (2006). ${ }^{5}$

This was not simply based on a misunderstanding of Iraq's federal constitution, but on wider regional concerns. ${ }^{6}$ What Paul Vallely calls 'the vicious schism between Sunni and Shi'a across the Middle East' exacerbates a broader problem (2014); 'rather than being coherent states with a strong sense of identity, they are artificial creations of colonial powers... They have international recognition, but no common traditions or ideals bind them together. Loyalty is based on ethnic, regional or sectarian affiliation: One is a Kurd, a Shi'a or a Sunni, not an Iraqi... the stage is set for conflict' (David 2007, p. 28). As a former senior CPA adviser put it, 'Middle Easterners culturally are unable to bring themselves to "let bygones be bygones". Sectarian violence will thus continue in perpetuity - or, he continues, 'until Allah decides which side is the most worthy' (Rhode 2012). Rather than a response to the political and economic policies of a government imposed through external force of arms, the recent ongoing truculence of Iraq's Sunni Arabs is thus simply one example of this eternal and immutable trend. The transnational and eschatological appeal of fighting the Baghdad administration and its Western backers is, for commentators like Douglas Murray, evidence that 'the region as a whole may be starting to go through something similar to what Europe went through in the early 17th century during the Thirty Years' War, when Protestant and Catholic states battled it out' (2014). For the insurgents, then, 'different readings of history, theology and religious law' are said to 'perform the same role as... the primordial or near-primordial ties of race, language, [and] ethnicity' (Nasr 2006, p. 23).

This kind of analysis shares, as Eller and Coughlan note, three fundamental assumptions (1993 p. 187). The first is that the identities to which Murray and others refer are a priori. Attachments are 'natural' givens, underived from social experience. The second is that they are ineffable. Those 
identified as a part of a group are bound together 'at least in great part by virtue of some unaccountable absolute import attributable to the very tie itself (Geertz 1973, p. 259). The third is that they are affective. The feelings that are said to underpin such 'primordial' attachments are, as manifestations of the supra-family, arbitrarily assumed to outweigh other forms of identity such as gender, class, party and so on. Culture, race, ethnicity, religion and so on are, as the principal manifestations of this (apparently innate) drive to coalesce, thus not created by social interaction, but prefigure it. A sectarian attachment is a result of immutable forces operating outside individual control. Little more can be said about its genesis or the 'more mundane practices that might act to produce or reproduce it' (Eller and Coughlan 1993, pp. 193-4). The Balkans and the Middle East are just the way they are - their politics are driven by an unknowable, ancient patchwork of hatreds too mysterious and irrational to be amenable to sociological explanation. As Fouad Ajami wrote of the latter during the build-up to the invasion of Iraq, 'this is one of those settings where a reforming foreign power's simpler guidelines offer a better way than the region's age-old prohibitions and defects' (2003, p. 2). Rejecting such superciliousness, the following sections demonstrate that, far from being a natural, selfexplanatory outgrowth of endemic conflicts hitherto suppressed by Ba'athi supervision, the violence that has so badly affected post-2003 Iraq is a result of contingent and analysable political developments.

\section{For the People, Of the People, By the Coalition}

Perhaps the most profound source of this ordering (or reordering) has its roots in the CPA's attempts to create a constitutional basis for the new political elite that it hoped would govern Iraq long-term. Seeking to maximise social legitimacy, it enacted a series of political interventions that emphasised sub-national identities, empowered sectarian parties within a new political structure, and enhanced competition between Sunni and Shi'a Arabs, changing their perceptions of the state and of themselves as citizens. Despite there being no reliable demographic data (the last nationwide census having been carried out in 1987), the Coalition appointed a 25 -member Iraqi Governing Council (IGC) within weeks of President Bush's infamous "mission accomplished" speech aboard the USS Abraham Lincoln in May 2003. Influenced by the exiled Iraqi elites which the West had nurtured during the 1990s (9 of whom made it on to the Council itself), the

allocation of its seats was explicitly sectarian: 13 for Shi'a Arabs, five for Sunni Arabs, five for 
Kurds, one for the Turkmen and one for the Assyrians. ${ }^{7}$ Described by Adeed Dawisha as 'the one decision that would open the way for the institutionalization of ethnosectarianism in the country's body politic', the announcement led to an almost immediate rise of identity politics in Iraq, reflected in the rapid formation of parties targeting specific social groups, often in a single geographical space (2009, p. 245). As an Iraqi parliamentarian declared, 'we awoke one day in [the Baghdad neighbourhood of] Adhamiya and suddenly discovered that we are all Sunnis' (quoted in International Crisis Group 2013, pp. 4-5). The fact that the bulk of the IGC's membership came from outside the country (16 even held alternative nationalities) meant that they lacked any firm grounding in Iraqi society (Jawad 2013, p. 11). In other words, political constituencies needed to be created and this pushed the new leadership towards tribes and sects as easy targets of their appeal.

The result was what Toby Dodge called an 'exclusive elite bargain' between the US and the ICG's dominant group of Shi'a activists, clergymen and intellectuals (2012, p. 40). The first element of this was the signing (by consensus) of a temporary legal framework, named the Transitional Administrative Law (TAL). Having abrogated Iraq's existing constitution -provisionally passed in 1970, but never ratified - the CPA drafted this new document using expatriate staff who were neither Arabic fist-language users nor constitutional lawyers (Arato 2009, p. 140). 'Hasty and secretive', it was imposed on the IGC who, despite extensive misgivings and a condemnatory fatwa from the country's most senior Shi'a cleric (Ayatollah Ali Sistani), endorsed it March 2004 (Morrow 2005, p. 5). Henceforth, it became the principal legal basis upon which the Interim Iraqi Government operated following the dissolution of the CPA in June of that year

The widely observed boycott of the January 2005 general elections produced an executive which greatly under-represented the Sunni Arab community, exacerbating the sense of a Shi'a political takeover. The 55-strong committee the new government appointed to prepare the TAL for a referendum in October contained 28 members of a parliamentary coalition dominated by two of the three largest Shi'a political organisations - the Supreme Council for the Islamic Revolution in Iraq (SCIRI) and the Dawa Party. Only one Sunni Arab participated initially. While 14 additional community leaders were later added, three were assassinated, reportedly due to their strong objection to the proposed draft, leading to withdrawals amid accusations that the killings had not been properly investigated. The committee was dissolved without final agreement, but revisions 
continued to be made by a six-man team made up of the leadership of the two main Kurdish parties, the SCIRI and the Dawa Party (Allawi 2007). Others requested attendance at these meetings, but were excluded. 'The expectation was quite clear: the Shia and Kurdish parties would agree to a constitutional text, which would then be presented as a fait accompli to the Sunni Arabs, who would be asked to take it or leave it' (Morrow 2005, p. 9). They mostly chose to leave it. The predominantly Sunni Arab governorates of Salah ad-Din and Anbar overwhelmingly rejected it, while the more mixed governorates of Diyala and Nineveh were approximately split down the middle. ${ }^{8}$

Rather than serving as a covenant that brings citizens together, though, the final draft of the constitution was triumphal and divisive. Its bizarre, ungrammatical and ranting preamble talks of 'international support from our friends', the 1982 reprisals against the Dawa party stronghold of Dujail, the 1991 uprising (using the term Sha'abaniyya - an annual supplication particularly associated with Shi'a religious practice) - and the military campaigns against the Kurds. While previous regime's statutes had studiously avoided referring to confessional identity, the term "sect" is mentioned five times, initially to define Iraq as 'a country of multiple nationalities, religions, and sects' (Article 3) and then specifically to inscribe the freedom to practice 'Hussieni [Shia] rituals' (no other religious rites are detailed). Perhaps most problematically, though, it reversed the TAL's previous commitment to the supremacy of national law. While the latter had precipitously introduced the notion of 'regional governments' based upon the nebulous idea of 'geographic and historical realities' (Article 4), it had ensured that (with the exception of the KRG) 'federal legislation supersede any legislation from other governmental units' (al-Istrabadi 2005-6, p. 274). Article 115 of the new constitution, however, stated that 'the priority goes to the regional law in case of conflict between other powers shared between the federal government and regional governments'. This not only opened the way for full Kurdish independence, but also laid the legal basis for the declaration of an autonomous Shi'a "region" made up of the southern governorates (an idea vaunted by members of the SCIRI before the invasion took place (Haddad 2014, p. 153)), thereby potentially 'facilitat[ing] the dissolution of the state... [and] leav[ing] the Sunni Arab community landlocked and without oil' (International Crisis Group 2006, pp.12-13).

The result was a retreat into communitarian identities and a rapid increase in internecine violence. While a civil war of growing proportions presented considerable military benefits to the Coalition 
as Iraqis turned inwards and attacks on international targets gradually declined, ${ }^{9}$ it quickly rendered much of the country ungovernable - thereby confirming the pre-invasion narrative that the country's component peoples were never going to be able to live together. By mid-2007, Biden and Gelb's so called "soft partition" thesis (summed up by Helene Cooper as a loose Kurdistan, a loose Shiastan and a loose Sunnistan, all under a big, if weak, Iraq umbrella'), had thus earned considerable support in Washington, even securing a 75-25 majority in a Senate vote later that year (2007). Overlooking the direct role the new constitution had played in the creation and reimagining of new sub-national social identities, this "Dayton-style solution" became both a way of explaining the ongoing violence 'as something natural that has been driven forward by the Iraqis themselves' and of legitimising a timetable for Western withdrawal (Visser 2007-8, p. 95). Portraying the Coalition as caught between two primordial and incommensurate blocs thereby distanced the impact of its policies from the source of the violence ("liberat[ing] ourselves from the notion that "we" have caused' the resultant fratricidal bloodshed, as Tony Blair put it (2014)). After all, by focusing on apparently religiously-inspired sectarian hatreds and 'denying the rational political demands of insurgent groups', it also helped to justify 'a restricted set of coercive and punitive counter-terrorism strategies, whilst simultaneously making non-violent alternatives such as dialogue, compromise and reform appear inconceivable and nonsensical' (Jackson 2007, p. 421).

\section{Counter-Insurgency and the Muhasasa}

Working from this assumption, the Coalition initially took the view that Sunni Arab opposition was limited 'to those fanatical enough or stupid enough not to realise that the old regime is dead' (Dodge 2004, p. 77). With the leadership of the two largest paramilitary forces - the SCIRI's Badr

Corps and the Kurdish peshmerga - firmly entrenched within the IGC and the Ba'ath's security apparatus dissolved (discussed in more detail below), occupation forces were generally content to make 'tactical arrangements with militias on an ad hoc basis' (Rathmell el al. 2005, p. 66). By early 2004, however, reports were pointing to a 'surge of Iraqi resistance... sweeping up thousands of people, Shiite and Sunni, in a loose coalition united by overwhelming anti-Americanism' (Gettleman 2004). Guerrilla units were operating in tandem across Baghdad's neighbourhoods and armed groups were issuing statements talking of a 'national struggle against the occupation, without confessional, ethnic or political distinction' (quoted in de la Grange 2004). The 
prominent Shi'a cleric, Muqtada al-Sadr sent a contingent of his newly-formed militia, the Mahdi Army, to assist the largely Sunni Arab uprising in Fallujah that Spring and 'the insurgency seemed to be on the cusp of a genuine Arab (i.e. incorporating Sunnis and Shia) war of national liberation against the foreign presence' (Hashim 2006, p. 130).

Alarmed, the Coalition accelerated its Transition and Reintegration Strategy by signing memoranda with the nine "compliant" militia that were controlled by members of the IGC in June 2004 (a similar agreement was concluded with al-Sadr in October of that year) and shortening the schedule for transferring their members into the security services from five years to 12 months (Mowle 2006, p. 47). ${ }^{10}$ Under the terms of the CPA's subsequent Order Number 91, 102,000 fighters were given the legal status of "residual elements" "that would allow their members to transition into government security forces or reintegrate into civil society through retirement or job training and placement' (Rathmell el al. 2005, p. 68). Special police commando units, made up of former Badr militiamen became immediately operational, fighting alongside American forces in Mosul in November 2004 (Davies 2010, p. 249). Following the January 2005 elections, this became the model for the expansion of counter-terrorism units within the national constabulary more broadly. According to the UK's Deputy Chief Police Advisor, Anthony Nott, the new Interior Minister, Baqir Jabr al-Zubeidi, 'broke[ ] free from his US mentor, Steve Casteel' and initiated 'a policy of removing all Sunnis' (2017, p. 182), replacing them with around 15,000 new recruits which, Casteel later claimed, included 'whole units' from the Badr brigades. ${ }^{11}$ With 'US offensives utilizing more and more Shia troops to fight against Sunni guerrillas', who the CPA continued to misconceive 'as inherently irreconcilable and as impervious to all but armed force', counter-insurgency policy became the " heavily politicised and took on a[n increasingly] sectarian character' (Schwartz 2008, p. 244; Ucko 2008, pp. 351-2).

With Shi'a militia already deployed to the Sunni Arab majority provinces in considerable numbers, the bombing of the al-Askari mosque in February 2006 led to an explosion of sectarian violence. ${ }^{12}$ In retaliation, the Badr-dominated police force, along with irregulars from the Mahdi army, launched a number of attacks targeting Sunni Arab insurgents as well as civilians (Damluji 2010, pp. 75-80). As the International Crisis Group concluded at the time, 'Iraqis witnessed a steep rise in killings of Sunnis that could not be explained by the fight against insurgents alone... prompt[ing] suspicions that they were carried out by Badr members operating under government 
identity' (2006, p. 3). The result was an acute political crisis - summed up by the United Nations as 'a generalized breakdown of law and order... [and] a growing perception of impunity for current and past crimes' (UNAMI 2006, pp. 1-2) . Ongoing public unhappiness at the handling of the constitutional referendum, combined with general dismay at the rising tide of violence combined to undermine confidence in the transitional Prime Minister and Dawa Party leader, Ibrahim al-Ja'afari. When he lost the backing of the SCIRI and was forced to rely on the staunchly anti-Coalition supporters of Muqtada al-Sadr following the elections of December 2005, President Bush replaced him with the then little-known Vice-Chair of the Higher National De-ba'athification Committee (HNDC), Nuri al-Maliki. Formerly leader of the Syrian branch of the Dawa Party (hitherto regarded as a terrorist organisation by the West after it was implicated in the bombings of the French and American embassies in Kuwait in 1983 (Abedin 2003)), he was - although 'shadowy and violent' - considered to be neither beholden to local paramilitaries, nor especially close to Tehran (Khedery 2014). He was, however, vehemently uncompromising on the issue of rooting out former Ba'athists - having promised the people of his home district, Hindiya, that 'our eyes will not shut until we retaliate' (Parker and Salman 2013, p. 70). ${ }^{13}$

Despite promising "reconciliation" then, al-Maliki's role and efforts consistently centred on promoting the Dawa party and organising retributions for actions undertaken under the past regime. This did little to reduce the ongoing violence, especially apparent in Baghdad where, despite having been characterised by its cosmopolitanism for centuries, over 700,000 people had to flee their homes during the first year of his administration (Tavernise 2006). While many Shi'a Arabs as well as Assyrian Christians were compelled to leave previously mixed areas of the city too, Sunni-Arabs were especially targeted (International Organization for Migration 2006). As Abu Kemael, a leader of a Mahdi Army unit, put it; it was very simple... anyone Sunni was guilty' (quoted in Cockburn 2008, p. 185). The level of fear this produced was indicated by the fact that many Iraqis attempted to change clearly Sunni names such as Omar, and some acquired two different gensiya (government identification cards) - one with their real details and another with a less identifiable appellation (Wong 2006). As an attempt to reduce the loss of life, the Coalition erected boundary walls between Sunni and Shi'a quarters of Baghdad from April 2007 onwards, amid considerable controversy. Despite a sustained opposition campaign from local residents, this imposed a physical structure of segregation upon the city, dividing communities which had been neighbours for centuries and rendering reconciliation markedly more difficult 
(Niva 2008).

Concurrently, the higher echelons of government were becoming increasingly 'dominated by members of Maliki's family and individuals who were tied to him personally from within the ranks of his party' (Platteau 2017, p. 248). His son Ahmed, for instance, was appointed to lead the security forces. Other close collaborators from the Dawa party came back from exile to join the ranks of his government, wining high offices despite a lack of government experience (Parker and Salman 2013, p. 72). These men included a new protocol secretary, Abu Mujtahid, and Tareq Abdullah, his chief of staff, who together ran al-Maliki's intelligence gathering networks, along with a newly formed Office of Information and Security led by former Badr commander, Abu Ali al-Basri, which 'serve[d] as a supplementary instrument in facing his rivals' (Stan and Cepoi 2014, p. 6). Much of al-Maliki's counter-insurgency policy was implemented through another extraconstitutional body, the Office of the Commander in Chief. Created in early 2007, it quickly fell under the control of Lieutenant-General Farouq al-Araji. A senior figure from a high-profile family of al-Sadr supporters, he became associated with 'sectarian practices that disproportionately targeted Sunnis and in the purging of officers who had taken aggressive action against Shi'a militias' (Sullivan 2013, p. 11). Regularly over-ruling the Defence and Interior Ministries, its authority over elite security units (such as the Baghdad Brigade and the Counter Terrorism Service) gave al-Maliki an informal chain of command that $\mathrm{r}$ [an] directly from his office to the military commanders in the field (Sullivan 2013, p. 11).

The Prime Minister was able to effect such a personalisation of elite politics by using the muchreviled muhasasa system of sectarian quotas. Described by Reidar Visser as a 'non-territorial variant of the Biden plan' (2009), this has its roots in the CPA's belief that 'stability would be served by an interim Governing Council which reflected the ethnosectarian balance' (Boduszyński 2016, p. 114). Over time, political debate became more and more centred on which political institutions would be awarded to each bloc as a largely unregulated plethora of parties vied to gain control of the most lucrative areas of the public sector. As a one parliamentary finance committee member put it, 'in order to respect the principle of muhasasa, we decided that each minister should be in charge of employment in his ministry... and would recruit only from within his party' (Majeeda al-Timimi quoted in International Crisis Group 2016, p. 4). Not only did this greatly damage the competence and integrity of the civil service, it also 'sacrific[ed] the 
possibility of an alliance rooted in issue-based politics' (Visser 2010, p. 6), thereby forcing crosscommunal initiatives into increasingly chauvinistic structures of administration (such as alMaliki's successful categorization of the non-sectarian Iraqiyya coalition as representative of the Sunni vote during his 2010 re-election (Dodge 2012, pp. 152-7)).

In the absence of any reliable data on the actual demographic numbers that form a basis for the quotas, the idea that the mubasasa system, and even sectarianism more broadly, has been 'something that the ruling political parties created in order to maintain their privileges and power and then reinforced by deploying their affiliated armed groups' became particularly pronounced amongst the most (predominantly Sunni Arab) disenfranchised (Boduszyński 2016, p. 115). As insurgent activity rose to over 1000 attacks per week during early-2007, many parts of the country became ungovernable. In response, around 100,000 so-called sahwa (awakening) Sunni Arab irregulars were recruited by US military commanders to restore public order in western governorates such as Anbar, Diyala and Saladin. By the end of that year, the Coalition had added these paramilitary forces to its bio-metric, photographic payroll (worth $\$ 150$ million in 2008 alone) and had started to recast them as "concerned local citizens" (Long 2008, p. 77). While this succeeded in reducing violence (helping to structure over 800 negotiated ceasefires), it embedded still deeper the CPA's counter-insurgency policy in the extra-legal authority of neighbourhood strongmen, thereby weakening the central government. In other words, 'by forging local alliances with a motley collection of former Sunni Arab insurgents', the Coalition further embraced a 'divide and rule strategy' which was always likely to 'prevent the development of a genuinely unified Iraqi state' (MacDonald 2014, p. 214).

\section{Media Fragmentation}

The structure of Iraq's media sector has its roots in the Pentagon's Office of Special Plans (OSP), created in October 2002 as part of a general expansion of the Defense Department's regional

staff capacity. ${ }^{14}$ Overseen by Under-Secretary of Defense for Policy Douglas Feith, ${ }^{15}$ it set out plans to establish a team of "hand-picked" Iraqi media experts... for the USG/coalition sponsored information effort', envisaging the founding of a new television channel, radio station and weekly newspaper - the latter portentously including separate sections for Shi'a, Sunni and Kurdish news (United States Department of Defense 2002, pp. 1-2). The job of realising these 
plans was awarded (on a no-tender basis) to the intelligence-gathering contractor, Science Applications International Corporation (SAIC). An important campaigner for the removal of Saddam Hussein during the 1990s, it had previously employed the weapons inspector David Kay, Deputy Under Secretary for Defense for Policy (2003-2008) Ryan Henry and Feith himself (alRawi 2013, pp. 380-381). Despite having no media experience, SAIC had managed a $\$ 33$ million contract supporting Iraqi political elites in exile (Barlett and Steele 2007). This had been facilitated through its senior executive, Wayne Downing, who had also served as a consultant to Ahmed Chalabi's Iraqi National Congress. ${ }^{16}$

SAIC was awarded US $\$ 108.2$ million to establish and run the Iraqi Media Network (IMN). This was initially overseen by the former Voice of America director, Robert Reilly, who later went on to write extensively on what he saw as the debilitating effects of Sunni Islam's predominant theological traditions (to be contrasted with the Shi'a who - he proposes - continued to 'think for themselves') (2010, p. 16). Announced in June 2003 as a replacement for the Ministry of Information (dissolved a month earlier with the loss of more than 5,000 jobs), it rapidly came to be seen as a mouthpiece of the occupation, being regularly given 'a laundry list of CPA activities to cover' (prompting a string of resignations amongst senior executives) (Markakis 2016, p. 121). Amid a series of media closures under Order Number 14 which prohibited not only inciting violence, but also publishing material that is 'patently false and calculated to promote opposition to the CPA', only 24 per cent of local respondents regarded the IMN as "objective" (Hubbard 2007, p. 63; Rohde 2005-6, p. 12). As Iraqis took a greater role in the IMN during the transitional period, its outlets came to be increasingly seen as 'reflecting the views and goals of the Shia political parties' (Ridolfo 2012, p. 254-5). Since 'the CPA never drew a line separating the IMN's institutional administration from that of the state, its al-Iraqiya television channel, for instance, came under the leadership of Habib al-Sadr (a relative of the ISCI's Abdul Aziz al-Hakim) and Muhammad Jassim Khudayer, a senior Dawa Party official (al-Rawi 2012, p. 91). As a result, its programming started to place particular emphasis on the suffering of Shi'as under Saddam, the "martyrdom" of deceased Shi'a militia and the success of the government's counter-terrorism strategy - frequently consisting of Sunni Arab captives being forced to confess to their role in the insurgency (often following torture) (al-Rawi 2012, pp. 75-76).

Since the Coalition remained principally concerned with the military imperative of winning hearts 
and minds and lessening the immediate threat to its forces, it did little to deal with the media's growing sectarianism. Instead, it focused on placing favourable articles in the press through Iraqi journalists hired by defence contractors such as the Lincoln Group (which pursued a strategy entitled “Divide and Prosper") (Mazzetti and Daragahi 2005). It also worked with civil society organisations it saw as sympathetic. The Free Iraq Foundation (part of the Iraq-America Freedom Alliance - a network created to give a voice 'to Iraqis who are grateful for their newfound freedom'), for instance, was heavily funded to produce television and radio programmes supporting democratic rule (Barker 2008, p. 119; Markakis 2016, p. 134). It assisted in the 2004 film, Voices of Iraq in which the majority of contributors affirmed that 'life under the American occupation, however precarious, is preferable to the tyranny of Saddam Hussein' (Stevens 2004). It is directed by Rend al-Rahim (a cousin of Ahmed Chalabi and previously the IGC's ambassador to Washington) and its board members include Laith Kubba (a former spokesman for interim Prime Minister Ibrahim al-Jaafari) and Muhyi al-khateeb (the SecretaryGeneral of the IGC who issued the closure notice to Aljazeera in 2004, apparently due to its 'misbehavior towards' the al-Hakim family of Shi'a scholars) (IGCR Press Release Number 113 translated and reproduced in Talmon 2013, p. 1248).

The principal regulatory body overseeing these activities, the Communications and Media Commission (CMC), was developed in early 2004 and given the task of enforcing CPA Order 14. As Article 19 observed at the time, though, it was neither appropriately constituted nor adequately equipped to investigate and adjudge alleged breaches of the law. Moreover, the fact that its nine-member board was nominated by the Prime Minister without any clear selection criteria 'introduce[d] a real danger of political interference' (Article 19 2004, p. 13). As predicted, the interim 'government was soon able to get its people in place and effectively took control' of both the CMC and IMN boards (Awad and Eaton 2013, p. 16). By the autumn of 2004, it was issuing warnings to 'news organizations to reflect the government's positions in their reporting... or face unspecified action' (Price 2007, p. 17). With the electoral success of the Dawa Party the following year, state broadcasting became, in the words of the Iraqi President's media adviser, Hiwa Osman, 'more and more sectarian' (quoted in al-Rawi 2012, p. 91). The CMC did little to combat the IMN's growing 'pro-Shiite' policy and, instead, concentrated its monitoring on 'what [wa]s said against the government and its senior Shiite figures' (al-Rawi 2012, p. 93, 89). 
In all, the political institutions that the CPA put in place to manage the emergence of a private media sector in Iraq ultimately contributed to what one author described as a "Lebanonization" of the country's fourth estate (Cochrane 2006). Many of the estimated 150 newspapers, 80 radio stations and 21 television channels being founded in the first year of Bremer's administration (often by staff dismissed from the Ministry of Information) quickly began to operate in the vanguard of partisan political interests' (Rohde 2006, p. 14; Awad and Eaton 2013, p. 23). These 'ethno-sectarian empires' became, in the minds of the Iraqi public, 'tools of war' as society collapsed into internecine fighting during 2005 (al-Marashi 2012, p. 262). In other words, Iraq's media started to resemble what Ibrahim al-Marashi calls the 'tri-ethnic prism' through which foreign observers had long used to categorise its social divisions - that Iraq's 'religious and ethnic identities are mutually exclusive', that internal divisions do not 'undermine sectarian identity or solidarity', that 'national identity as a basis for political cohesion does not exist' and, as elite politics came to be dominated by the two major Shi'a blocs, the Dawa Party and the SCIRI, that 'Shi'ites and Kurds were victims' of a “Sunni”' Arab Ba'ath (2007, pp. 124-125; Bazzaz 2013, pp. 248-9).

\section{Economic Deconstruction}

The initial plan of the Office for Reconstruction and Humanitarian Assistance, the short-lived predecessor of the CPA, was to retain as much of Iraq's governmental infra-structure as possible. Only 'those who were part of the thug mechanism under Saddam' would be removed, its director, Jay Garner told Time magazine (Bennett 2003). Not wishing to 'throw the baby out with the Baath water', as his advisor Tim Carney put it, the post-war strategy was based 'on bringing the Iraqi army back and using them in reconstruction' (Garner and Carney quoted in Roberts 2003). With only the 55 individuals pictured on the infamous "most wanted" playing cards automatically disqualified from office, many of Saddam's appointees initially kept their jobs Hamid Othman as the capital's Chief of Police, Ahmad Rashid Gailini at the Trade Ministry, Ali Shnan al-Janabi as director of health and so on - with their ongoing roles to be determined through immediate elections (Ch and resekaran 2003). This was, however, neither what had been promised to Ahmed Chalabi and the other exiled elites courted by the West during the 1990s, nor a reliable way to ensure longer-term Coalition influence over Iraq's policies and resources. Garner was therefore dismissed in May 2003 and the CPA was created under Paul Bremer (a former 
assistant to Henry Kissinger, counter-terrorism diplomat under President Reagan and risk management executive).

Bremer arrived in Iraq two weeks after being offered the job. He had never been there before, 'did not speak Arabic, had never served in a post-conflict society and had no experience in nation building' (Cooper and Catchpowle 2009, p. 721). Four days after taking charge he issued CPA Order Number One entitled De-Ba athification of Iraqi Society. Drafted by the OSP, this dismissed all party members (above the rank of “Group Member') from their positions, banned them from future employment in the public sector announced a process of interviews in which each 'shall be evaluated for criminal conduct or threat to the security of the Coalition' (Section One, Paragraph Two). All members of the Ba'ath party, regardless of rank, would also be removed from the top three tiers of management in all national government ministries. Although Bremer later claimed that this only affected one per cent of party members (blaming the interim government for later excesses), General Sanchez, who assumed overall command of ground forces the following month, put the figure at between 85,000 and 100,000 - of whom, almost half were, according to the CIA (who opposed the policy) school teachers (Sanchez 2008, p. 184; Tenet 2007, p. 427).

A week later, Bremer issued CPA Order Number Two, Dissolution of Entities. ${ }^{17}$ This terminated the employment of all staff at the Ministries of Defence, Information and Military Affairs, as well as all branches of the intelligence, the armed forces, government and the security courts. Severance and pension payments would only be maintained for all those who were both below the rank of Colonel and not defined as party members under CPA Order Number One (Section Tree, Paragraph Six). This affected around 700,000 people, including the large numbers of officials who had heeded the Coalition's pre-invasion advice and not taken up arms against the incoming troops - 137,000 of whom had already registered a willingness to re-join a CPA-led military service (Pfiffner 2010, pp. 80-81). The immediate result of this was, as one Colonel from the Coalition's forces put it, 'a vacuum of disorder', of which 'insurgent groups readily took advantage' (Collins 2016). Undeterred, Bremer pressed on with the creation of the HNDC (CPA Order Number Five, May $25^{\text {th }}$ ) to be chaired by Ahmed Chalabi and Nuri al-Maliki. Alongside this, operated a special legal tribunal tasked to investigate the actions of former regime officials. It was directed by Chalabi's nephew who had returned to Iraq to run a law practice with the Israeli lawyer, Marc Zell (a former business partner of Douglas Feith (Whitaker 2003). 
More broadly, both these Orders destroyed the state's patrimonial networks. Civil society organizations, such as contractors' guilds, professional associations, chambers of commerce, trade unions and so on, were all rendered impotent almost overnight. With the CPA attempting to impose 'a blend of wild-eyed and hopelessly unrealistic radical reforms, supposedly to introduce a liberal market economy,' GDP per capita fell from \$1065 in 1999 to \$704 in 2004 while unemployment grew from 17 per cent in 1997 to 28 per cent in late 2003, amid a rapid rise in impoverishment (Allawi 2007, p. 123; Yousif 2010, p. 363; Yousif 2007, p. 48). Those that could simply left the country, leaving behind what Faleh A. Jabar calls 'the spearhead of the mafia world, militias, and insurgents'. Moreover, in 'destroying state patronage that was the very life line [sic] of rehabilitated tribes and all salaried and propertied middle classes', the Coalition, he continues, broke the cross-communal connections which had made up the fabric of Iraqi society for centuries. As public services collapsed, the overall result, he concludes, was that 'grand communal identity politics among Shi'is and Sunnis began to crystallize' in lieu of the state's presence, thereby forming multiple economic grounds for a growth in sectarianism (2011, p. 21).

Although attempts were made to reverse the policy, Bremer claims that they were stymied 'by the dominant Shia and Kurdish political factions in Baghdad' (Bremer, Dobbins and Gompert 2008, p. 32). ${ }^{18}$ It is certainly the case that both the Coalition and Allawi's interim administration were unable to prevent Ahmed Chalabi using his chairmanship of the HNDC to focus the 'greater bulk of his efforts towards establishing Shia dominance in the evolving political system'. ${ }^{19}$ With his ascendency to Deputy Prime Minister (held jointly with Oil portfolio) within al-Ja'afari's new government in 2005, the search for former regime loyalists became a powerful 'form of patronage' within the public-sector (Khan 2014). As the International Crisis Group noted at the time, whereas 'Shiite Baath party members... [were given] the opportunity to repent', the standard approach to Sunni Arabs was 'to exclude them from senior posts in government and the security forces' (cited in Steele 2008, p 204). When Chalabi's deputy, Nuri al-Maliki, became Prime Minister in 2006, de-ba'athification became a core method of ensuring Dawa Party supremacy. There was, for instance, the 'wholesale firing of Sunni commanders in favor of more compliant, if less competent, Shi'ites during his 2006-2014 tenure', thereby turning 'what was supposed to have been a national army into little more than a sectarian militia' (Thompson 2015). On a local level, it was, as one Mahdi Army operative put it, 'easy enough to label a Sunni whose 
property somebody else wanted as a Baathist official and take it' (quoted in Cockburn 2008, p. 185)

This contributed to what Ali Allawi calls an 'explosion in corruption' - not in order 'to generate funds... for the government's discretionary use' (which, Allawi argues, was the predominant pattern of deception during the 1990s), 'but for the private enrichment of officials and their supplier cronies' (2007, p. 353). The initial source of these income streams came from the Development Fund for Iraq (DFI) administered by the CPA. Derived from unspent Oil for Food allocations under the terms of United Nations Resolution 1483, it was specifically covered by President Bush's Executive Order 13303 (May 28 2003) which provided legal immunity for prosecution for anyone involved in its disbursement - a guarantee of impunity extended to all CPA contractors in Bremer's subsequent Order Number 17. ${ }^{20}$ 'Subject to negligible bureaucratic controls' and in violation of international law, DFI monies arrived in \$1.6 million "cashpaks" to fund reconstruction projects, of which three-quarters were commissioned through noncompetitive tenders (Whyte 2007, pp. 184, 187). When an auditor (KPMG Bahrain) was eventually appointed in 2004, it was found that $\$ 8.7$ billion of the $\$ 9.19$ billion the US Defense Department received from the DFI 'was not properly accounted for' (al-Ali 2014, p. 195).

Table One: Selected Millennium Development Goals Indicators within Three Sunni Arab Majority Governorates in Iraq (Ministry of Planning 2012)

\begin{tabular}{|c|c|c|c|c|c|c|c|c|}
\hline & \multicolumn{2}{|c|}{$\begin{array}{l}\text { Anbar } \\
2006 / 7 \quad 2011\end{array}$} & \multicolumn{2}{|c|}{$\begin{array}{l}\text { Nineveh } \\
2007 \quad 2011\end{array}$} & \multicolumn{2}{|c|}{ Salah-a-Din } & $\begin{array}{l}\text { Iraq } \\
2007\end{array}$ & 2011 \\
\hline $\begin{array}{l}\text { Spending less than } \\
\$ 2.5 \text { a day }(\%)\end{array}$ & 12.2 & 12.5 & 13.3 & 26 & 27.8 & 6.9 & 13.9 & 11.5 \\
\hline $\begin{array}{l}\text { Infant mortality } \\
\text { per } 1000 \text { births }\end{array}$ & 28 & 31.9 & 35 & 39.7 & 57 & 35.4 & 35 & 31.9 \\
\hline $\begin{array}{l}\text { Net enrolment in } \\
\text { secondary } \\
\text { education }(\%)\end{array}$ & 49.2 & 45.3 & 27 & 41.2 & 34.7 & 43.4 & 40.1 & 48.6 \\
\hline $\begin{array}{l}\text { Children } \\
\text { vaccinated against } \\
\text { measles }(\%)\end{array}$ & 77.5 & 66.2 & 80.4 & 72.1 & 77.4 & 57.8 & 69.3 & 75.4 \\
\hline
\end{tabular}

As Iraq fell from $113^{\text {th }}$ to $178^{\text {th }}$ in Transparency International's Corruption Perceptions Index during the following three years, 'the growth of militias within ministries created polarizing 
power centres that... transformed corruption into a political agenda... by backing sectarian groups' (Sassoon 2016, p. 26). Since these came to be increasingly under the control of successive administrations dominated by Shi'a elites, it has been the Sunni Arabs that have been most acutely affected (an estimated 10 per cent of whom - ten times the proportion of Germans affected by de-Nazification measures at the end of the Second World War - have been subject to the HNDC's lustrations) (Gaub 2017). This, combined with the fact that almost half the civilian deaths occurring outside Baghdad have taken place within the governorates of Anbar, Nineveh, Salah-a-Din, has produced a collapse public services and thus, as Table One shows, a marked decline in the living standards of many Sunni Arabs in relation to the country as a whole (Hicks et al. 2011). 'With little political recourse to rectify its grievances.... [the region's citizenry therefore] grew increasingly susceptible to calls for armed resistance from disgruntled Sunni [Arab] elites' (al-Gharbi 2014).

\section{Conclusion}

Accepting the weight of pre-invasion policy opinion that the Middle East is a fragmented patchwork of mutual hostilities, Paul Bremer saw himself and his team at the CPA as 'the custodians of Iraqi unity' (2006, p. 296). Working from the three key premises of primordialism that social identities are natural, ineffable and determinative (Eller and Coughlan 1993) - his 'idée fixe was' Reidar Visser observes, 'that Iraq's political problems resulted from an imperfect correlation between its demographic composition and the structure of its governing elite' (20078, p. 93). In other words, by continuing to view the social basis of these leaders' authority as not a creation of contingent and fluid attachments driven by contemporary events, but as a stable and immutable result of ancient antagonisms, Bremer conflated political access with communal organisation. The result was that the principal 'ordering device' (as Mueller puts its) in the development of the nascent state (particularly the appointment of the IGC and the drafting of a new constitution) became sub-national identity (2000, p. 62).

Tertius gaudens, this offered the Coalition some benefits - 'as long as Iraqi leaders were fighting over sub-national interests, the overall direction of the country could be shaped from outside' (Muttitt 2012, p. 158). Indeed, with counter-insurgency policy being guided by General Sanchez's warning of the need to ensure that a linkage between the Sunni and Shia... remains at the tactical 
level' and does not become a concerted resistance strategy (quoted in Schwartz 2008, p. 109), remodelling the country's state institutions along primordial lines usefully 'prevented the emergence of a strong nationalist form of Iraqi politics' (Ismael and Ismael 2010, p. 345). Since the Coalition's coterie of what Toby Dodge calls 'ethnic and religious entrepreneurs', were mostly from outside the country and therefore lacked established constituencies (Marr 2006, p. 8), they attempted to gain support by mobilising 'what have previously been passive, irrelevant, or nonpolitical identity traits'. Operating through a poorly regulated media sector (the independence of which had been compromised by the CPA from the outset), they derived authority from the violence itself. After all, as Dodge continues, 'in circumstances of profound uncertainty, people will turn to whatever grouping, militia, or identity offers the best chance of survival' (2014, p. 5).

This is particularly so during periods of acute economic pressure. Although the way in which 'post-invasion economic policies facilitated a rise in sectarian tensions between the Sunnis and Shi'a [Arabs] is rarely discussed', the CPA's policy of mass dismissals (while also introducing considerable pay rises for retained workers) doubtlessly 'magnified the sense of gain and loss in society at large' (Yousif 2006, p. 497; Yousif 2007, p. 44). Almost ubiquitously associated with the previous regime and hosts to the brunt of the fighting and this was especially felt by the Sunni Arabs, many of whose neighbourhoods were becoming increasingly impoverished. Lacking access to political recourse comparable to that of other sections of Iraqi society, separatist pressures on their otherwise largely national response gained currency - initially retrenched by the sabwa initiative (which served to weaken the central government further) and then ultimately resurgent in 2013 with the emergence of the Islamic State. Both these dynamics and the mobilisation of the various Shi'a combat militia since 2003 are rooted in the state-building structures of the CPA, not the misty pasts of confessional difference. As Eric Davis concludes, the 'sectarianism that currently exists is the result of Iraq's political economy, rather than "ancient hatreds" and it is this struggle for social power, within the parameters set by the Coalition, which turned 'Iraqis into sectarian extremists of a kind completely alien to the country's long history of sectarian coexistence' (Visser 2007-8, p. 93).

\section{Notes}

${ }^{1}$ Testimony given to the House Of Representatives Hearing before the Committee on Oversight 
and Government Reform, The Impact of CPA Decisionmaking [sic] on Iraq Reconstruction, February 6, 2007. Available from: https://www.gpo.gov/fdsys/pkg/CHRG110hhrg36545/html/CHRG-110hhrg36545.htm [accessed 4 May 2017].

${ }^{2}$ Quoted in Cockburn 2008, p. 185.

${ }^{3}$ Monthly civilian fatalities are estimated to have increased from mostly less than 1000 during 2003 to over 3500 by mid-2007 (O’Hanlon and Campbell 2008, p. 4).

${ }^{4}$ A recent commentary captures the popular understanding of this narrative quite well: 'Iraq was a country ruled by a Sunni, Saddam Hussein, in which a majority of the people were Shiites. Potential conflict there? You bet. Saddam, however, kept the lid on this seething cauldron. Getting rid of him took the lid off (Lawrence 2015).

${ }^{5}$ According to retired admiral and current dean of Tufts' Fletcher School, James Stavridis, Syria should also be presented with its own Dayton Accords, dividing the country into an 'Alawite rump state, .... Kurdish enclave' and a Sunni centre (2015).

${ }^{6}$ The governorates to which power is devolved are not drawn along such sectarian lines and therefore could not be 'combine[d] into regional governments' as Biden and Gelb claim (Visser 2007: 91).

${ }^{7}$ It is important to note that this was the first time in Iraq that a governing body was formed along explicitly ethnosectarian lines. Under Saddam Hussein's rule, although the Shi'a and other groups suffered discrimination on several levels, open talk about sectarian identities was a taboo. In fact, the Ba'ath regime emphasised the Arab identity of the state and its population, in contrast to the external Iranian (and, intermittently, the internal Kurdish) enemy. As such, Iraqis were not allowed to speak in sectarian terms, and the terms "Sunni" and "Shi'a" were rarely heard in public (Haddad 2014, p. 155).

${ }^{8}$ With almost 80 per cent voting in favour, the CPA claimed that the referendum represented a clear endorsement of the constitutional process. In reality, though, it only narrowly passed - if in Nineveh (where just 57 per cent of the electorate turned out) there had been a 10 point increase in the rejection rate, there would have been the three-governorate super-majority (written into the TAL to give the KRG a veto) necessary to vote it down.

9 The monthly casualty rate for US troops, for instance, declined from around 70 fatalities between March 2003 and August 2007 to less than 30 for the following 18 months (O'Hanlon and Campbell 2008, p. 17).

${ }^{10}$ Other than the two Kurdish Parties, the renamed Badr Organisation, Chalabi's Iraqi National Accord, Allawi's Iraqi National Congress and the armed wing of the Dawa Party, those militia covered by the memoranda included Kata'ib Hezbollah (believed to be led by one of Ibrahim alJa'afari's security advisors) which is now on the State's Department's list of foreign terrorist organisations. The other two were the Communist and Islamic Parties, represented on the IGC by Hamid Majid Mousa and Mohsen Abul Hamid respectively.

11 These allegations were put to the Minister in an interview with the US network, Public Broadcasting Service, in November 2006 (http://www.pbs.org/wgbh/pages/frontline/gangsofiraq/interviews/jabr.html). Casteel's claims were corroborated by Matt Sherman, a legal adviser to the Ministry of Interior, who confirmed 
that 'leadership in the commando positions has been turned over to Badr' (quoted in Allbritton 2006).

${ }^{12}$ Witnesses report that, although officially blamed on "Sunni insurgents", the attack was carried out by men wearing 'commando uniforms like those issued by the Interior Ministry' (Santora 2007).

${ }^{13}$ Shortly afterwards, Ahmad Najat, the government officer who had led a hunt for members of the Dawa party in Hindaya in 1979, was brought to the town and executed in the street.

${ }^{14}$ Although quickly renamed "Northern Gulf Affairs", it gained notoriety in 2007 after its actions were investigated by the Deputy Inspector General for Intelligence and excoriated for overstating the Iraqi regime's alleged connections to international terrorism (see United States Senate Committee on Armed Services Hearing, 2007).

${ }^{15}$ Feith had been part of a study group contributing to a report for incoming Israeli Prime Minister Netanyahu which advocated replacing the Saddam regime with a restored Hashemite monarchy in 'central Iraq' as part of 'a redrawing of the map of the Middle East which would threaten Syria's territorial integrity' and weaken Najafi Shi'a influence over south Lebanon (Institute for Advanced Strategic and Political Studies 1996, pp. 3-4). While Feith has consistently denied that improved Israeli security was a policy concern in Iraq, he does not distance himself from the report's key theses (http://www.dougfeith.com/cleanbreak.html).

${ }^{16}$ General Downing had previously served as Commander-in-Chief of Special Operations Command. He, Chalabi and Duane Clarridge (a former chief of the CIA's European Division indicted over the Iran-Contra scandal in 1991) devised what became known as the "enclave" plan to attack Iraq in 1998 (Ahmad 2014, p. 130). In this approach, 'Iraqi opposition groups, supported by US air power, would create a base in southern Iraq... [from which] Saddam's opponents could then foment a rebellion across the country' (Solomon 2007, p. 89). Strongly advocated by Under Secretary of Defense Wolfowitz, it meant that the support of the Shi'amajority governorates was crucial (Loeb 1998).

${ }^{17}$ This decision ran contrary to both the State Department's and the Army War College's pre-war plans (Fallows 2004). Feith believed, however, that 'the facts on the ground had changed' (2009, p. 432, italics in original). The Coalition's most senior security adviser, Walter Slocombe (who had been Feith's predecessor at the Defense Department) agreed and the announcement was apparently made with little prior consultation (Ricks 2008, p. 163).

${ }^{18}$ Director of Central Intelligence Tenet reports that these efforts were actually obstructed by Feith who argued that any reversal would 'undermine the entire moral justification for the war' (2007, p. 428).

${ }^{19}$ Bremer did attempt to shut down the Commission in April 2004, but Ahmed Chalabi argued successfully that this was unconstitutional. Allawi then withdrew the security clearance of some of the Commission's members and had its director, Mithal al-Alusi, arrested and removed from post (Otterman 2005). He also secured the resignation of Salem Chalabi later that year after he was indicted for the murder of a finance ministry official, who, it was alleged, was attempting to investigate Chalabi's affairs (Whitaker and Howard 2004). 
${ }^{20}$ Executive Order 13303 stated that 'any attachment, judgment, decree, lien, execution, garnishment, or other judicial process is prohibited' with respect to the DFI and the Iraqi petroleum industry (full text available from: https://www.treasury.gov/resourcecenter/sanctions/Documents/13303.pdf). Section Four (Paragraph Three) of Order Number 17 specified that 'contractors shall be immune from Iraqi legal process with respect to acts performed by them pursuant to the terms and conditions of a Contract or any subcontract thereto text available from: ww.usace.army.mil/Portals/2/docs/COALITION_PROVISIONAL.pdf) [accessed 4 May 2017].

\section{References}

Abedin, M., 2003. Dossier: Hezb al-Daawa al-Islamiyya. Middle East Intelligence Bulletin, 5 (6) [online edn.]. Available from: https://www.meforum.org/meib/issues/0306.htm [accessed 4 May 2017].

Ahmad, M. I., 2014. Road to Iraq: the making of a neoconservative war. Edinburgh: Edinburgh University Press.

Ajami, F., 1993. The summoning. Foreign Affairs, 72 (4), 2-9.

Ajami, F., 2003. Iraq and the Arabs' future. Foreign Affairs, 82 (1), 2-18.

al-Ali, Z., 2014. The struggle for Iraq's future: how corruption, incompetence and sectarianism have undermined democracy. New Haven CT: Yale University Press.

Allawi, A. A., 2007. The occupation of Iraq: winning the war, losing the peace. New Haven CT: Yale University Press

Allbritton, C., 2006. Why Iraq's police are a menace. Time, 20 March [online edn.]. Available from: http://content.time.com/time/world/article/0,8599,1175055,00.html [accessed 4 May 2017].

Arato, A., 2009. Constitution making under occupation: the politics of imposed revolution in Iraq. New York: 
Columbia University Press.

Article 19, 2004. Memorandum on draft Iraqi media laws. London.

Awad, A. and Eaton, T., 2013. The media of Iraq ten years on: the problems, the progress, the prospects. London: BBC Media Action Policy Briefing 8 (March).

Barker, M., 2008. Democracy or polyarchy? Us-funded media developments in Afghanistan and Iraq post9/11. Media, Culture and Society. 30 (1), 109-130.

Barlett, D. L. and Steele, J. B., 2007. Washington's $\$ 8$ billion shadow. Vanity Fair, 6 February [online edn.]. Available from: https://www.vanityfair.com/news/2007/03/spyagency200703 [accessed 4 May 2017].

Bazzaz, S., 2013. The discursive mapping of sectarianism in Iraq: The Sunni Triangle in the pages of The New York Times. In: S. Bazzaz, Y. Batsaki, and D. Angelov, eds. Imperial geographies in Byzantine and Ottoman space. Cambridge MA: Harvard University Press, 245-262.

Bennett, B., 2003. Sorting the bad from the not so bad. Time, 11 May [online edn.]. Available from: http://content.time.com/time/magazine/article/0,9171,450991-2,00.html [accessed 4 May 2017].

Biden, J. and Gelb, L., 2006. Unity through autonomy in Iraq. The New York Times, 1 May [online edn.]. Available from: http://www.nytimes.com/2006/05/01/opinion/01biden.html?pagewanted $=$ all\& $r=0$ [accessed 4 May 2017].

Blair, T., 2014. Iraq, Syria and the Middle East - an essay by Tony Blair. The Office of Tony Blair, 14 June [online edn.]. Available from: http://www.tonyblairoffice.org/news/entry/iraq-syria-andthe-middle-east-an-essay-by-tony-blair/ [accessed 4 May 2017].

Boduszyński, M. P., 2016. Iraq’s year of rage. Journal of Democracy, 27 (4), 110-124. 
Bremer, L. P., 2006. My year in Iraq: the struggle to build a future of hope. New York: Simon and Schuster.

Bremer, L. P., Dobbins, J. and Gompert, D., 2008. Early days in Iraq: decisions of the CPA. Survival, 50 (4), 21-56.

Burleigh, M., 2014. The ancient Muslim hatreds tearing apart the Middle East. Daily Mail, 13 June [online edn.]. Available from: http://www.dailymail.co.uk/news/article-2656734/Ancienthatreds-tearing-apart-Middle-East-How-1-400-year-old-feud-Shia-Sunni-Muslims-flared-life-falldictators-like-Gaddafi-Saddam-threatens-swallow-Iraq.html [accessed 4 May 2017].

Çağaptay, S., 2004. The problem within Islam. The Weekly Standard, 29 February [online edn.]. Available from: http://www.weeklystandard.com/the-problem-within-islam/article/5013 [accessed 4 May 2017].

Ch and rasekraran, R., 2003. U.S.. inflames some Iraqis bringing back Baathists. The Washington Post, 7 May [online edn.]. Available from: https://www.washingtonpost.com/archive/politics/2003/05/07/us-inflames-some-iraqisbringing-back-baathists/39949f74-50a3-4bac-a084-ffc7a8cf5412/?utm term $=.45875 \mathrm{bd} 70054$ [accessed 4 May 2017].

Cochrane, P., 2006. The 'Lebanonization' of the Iraqi media: an overview of Iraq's television landscape. Transnational Broadcasting Studies, 16 (Spring) [online edn.]. Available from: http://tbsjournal.arabmediasociety.com/Cochrane.html [accessed 4 May 2017].

Cockburn, P., 2008. Muqtada Al-Sadr, The Shia revival, and the struggle for Iraq. New York: Scribner.

Collins, T., 2016. We knew the occupation of Iraq would be a disaster - and did nothing. The Telegraph, 6 July [online edn.]. Available from: http://www.telegraph.co.uk/news/2016/07/06/we-knew-the-occupation-of-iraq-would-be-adisaster----and-did-no/ [accessed 4 May 2017]. 
Cooper, H., 2007. Iraq math. From one, make three. The New York Times, 29 July [online edn.]. Available from: http://www.nytimes.com/2007/07/29/weekinreview/29cooper.html [accessed 4 May 2017].

Cooper, C. and Catchpowle, L., 2009. US imperialism in action: An audit-based appraisal of the Coalition Provisional Authority in Iraq. Critical Perspectives on Accounting, 20 (1), 716-734.

Damluji, M., 2010. 'Securing democracy in Iraq': sectarian politics and segregation in Baghdad, 2003-2007. Traditional Dwellings and Settlements Review, 21 (2), 75-80.

David, S., 1992. Why the Third World still matters. International Security, 17 (3), 127-159.

David, S., 2007. On civil war. The American Interest, 2 (4), 23-32.

Davis, E., 2007. Rebuilding a non-sectarian Iraq. Strategic Insights, 6 (6), 1-11.

Davies, N., 2010. Blood on our hands: the American invasion and destruction of Iraq. Ann Arbor MI: Nimble Books,

Dawisha, A., 2009. Iraq: a political bistory from independence to occupation. Princeton NJ: Princeton University Press.

de la Grange, A., 2004. The liberation of Baghdad is not far away. Asia Times, 25 June [online edn.]. Available from: http://www.atimes.com/atimes/Middle East/FF25Ak07.html [accessed 4 May 2017].

Dodge, T., 2004. Iraq and the perils of regime change: from international pariah to fulcrum of regional instability. In: C. P. Hanelt, G. Luciani and F. Neugart, eds. Regime Change in Iraq: the transatlantic and regional dimensions. Florence: European University Institute, 65-82.

Dodge, T., 2012. Iraq: From war to a new authoritarianism. New York: Routledge. 
Dodge, T., 2014. Seeking to explain the rise of sectarianism in the Middle East: the case study of Iraq. In: Iraq between Maliki and the Islamic State. POMEPS Briefings 24: George Washington University, 4-9.

Eller, J. D. and Coughlan, R. M., 1993. The poverty of primordialism: the demystification of ethnic attachments. Ethnic and Racial Studies, 16 (2), 183-201.

Fallows, J., 2004. Blind into Baghdad. Atlantic Monthly, January/February, 52-74.

Feith, D. J., 2009. War and decision: inside the Pentagon at the dawn of the War on Terrorism. New York: Harper.

Finney, P., 2010. The land of ghosts? Memories of war in the Balkans. In: G. Kassimeris and J. Buckley, eds. The Ashgate research companion to modern warfare. Farnham: Ashgate, 343-363.

Gaub, F., 2017. Meet Iraq's Sunni Arabs: A strategic profile. European Union Institute for Security Studies, Issue Brief 26 [online edn.]. Available from: https://www.iss.europa.eu/content/meet-iraqs-sunni-arabs- $\% \mathrm{E} 2 \% 80 \% 93$-strategic-profile [accessed 4 May 2017].

al-Gharbi, M., 2014. The myth and reality of sectarianism in Iraq. Aljazeera America, 18 August [online edn.]. Available from: http://america.aljazeera.com/opinions/2014/8/iraqsectarianismshiassunniskurdsnourialmalaki.html [accessed 4 May 2017].

Geertz, C., 1973. The interpretation of cultures. New York: Basic Books.

Gettleman, J., 2004. The struggle for Iraq: insurgents; anti-U.S. outrage unites a growing Iraqi resistance. The New York Times, 11 April [online edn.]. Available from: http://www.nytimes.com/2004/04/11/world/struggle-for-iraq-insurgents-anti-us-outrageunites-growing-iraqi-resistance.html [accessed 4 May 2017]. 
Gunter, F. B., 2013. The political economy of Iraq: restoring balance in a post-conflict society. Gloucester: Edward Elgar.

Haddad, F., 2014. A sectarian awakening: reinventing Sunni identity in Iraq after 2003. Current Trends in Islamist Ideology, 17 (4), 145-76.

Hashim, A. S., 2006. Insurgency and counter-insurgency in Iraq. Ithaca NY: Cornell University Press.

Herring, E. and Rangwala, G., 2006. Iraq in fragments: the occupation and its legacy. Ithaca: Cornell.

Hicks, MH-R., Dardagan, H., Guerrero Serdán, G., Bagnall, P. M., Sloboda, J. A. and Spagat, M., 2011. Violent deaths of Iraqi civilians, 2003-2008: analysis by perpetrator, weapon, time, and location. PloS Med, 8 (2), 1-15.

Hinde, R., 1993. Aggression and war: individuals, groups and states. In: P. Tetlock, J. Husbands and R. Jervis, eds. Behaviour, society and international conflict vol. III. Oxford: Oxford University Press, $9-70$.

Hubbard, Z. P., 2007. Information operations in the Global War on Terror: Lessons learned from operations in Afghanistan and Iraq. In: L. Armistead, ed. Information warfare: separating bype from reality. Washington: Potomac Books, 45-72.

Institute for Advanced Strategic and Political Studies, 1996. A clean break: a new strategy for securing the realm. Jerusalem.

International Crisis Group, 2006. The next Iraq war? Sectarianism and civil conflict. Middle East Report, 52.

International Crisis Group, 2013. Make or break: Iraq's Sunnis and the state. Middle East Report, 144.

International Crisis Group, 2016. Fight or flight: the desperate plight of Iraq's "Generation Page | 29 
2000”. Middle East Report, 169.

International Organization for Migration, 2006. Iraq displacement: 2006 year in review. Geneva.

Ismael, T. Y. and Ismael, J. S., 2010. The sectarian state in Iraq and the new political class. International Journal of Contemporary Iraqi Studies, 4 (3), 339-356.

Istrabadi, F. A., 2005-6. Reviving constitutionalism in Iraq: key provisions of the Transitional Administrative Law. New York Law School Review, 50 (1), 269-302.

Jabar, F. A., 2011. Religion, sect, ethnicity and tribe. In: A. Paya and J. L. Esposito, eds. Iraq, democracy and the future of the Muslim World. Abingdon: Routledge, 19-35.

Jawad, S. N., 2013. The Iraqi constitution: structural flaws and political implications, LSE Middle East Center Paper Series 01.

Kaplan, R., 1993a. Balkan ghosts: a journey through history. Basingstoke: Picador.

Kaplan, R., 1993b. A reader's guide to the Balkans. The New York Times, 18 April [online edn.]. Available from: http://www.nytimes.com/1993/04/18/books/a-reader-s-guide-to-thebalkans.html?pagewanted $=$ all [accessed 4 May 2017].

Kaufman, M., 1999. The dangers of letting a president read. The New York Times, 22 May [online edn.]. Available from: http://www.nytimes.com/1999/05/22/books/the-dangers-of-letting-apresident-read.html [accessed 4 May 2017].

Khan, M., 2014. Watch for the economic fallout as ISIS extends its power. The Daily Star (Lebanon), 15 August [online edn.]. Available from: http://www.dailystar.com.lb/Opinion/Commentary/2014/Aug-15/267262-watch-for-theeconomic-fallout-as-isis-extends-its-power.ashx\#sthash.pvcZBoto.dpuf [accessed 4 May 2017].

Khedery, A., 2014. Why we stuck with Maliki — and lost Iraq. The Washington Post, 3 July [online Page | 30 
edn.]. Available from: https://www.washingtonpost.com/opinions/why-we-stuck-with-maliki-and-lost-iraq/2014/07/03/0dd6a8a4-f7ec-11e3-a606-

946fd632f9f1 story.html?utm term=.5e1c12873922 [accessed 4 May 2017].

Lawrence, J., 2015. A centuries old Sunni-Shiite conflict is at heart of Middle East problems. San Diego Free Press, 1 December [online edn.] Available from: http://sandiegofreepress.org/2015/12/a-centuries-old-sunni-shiite-conflict-is-at-heart-ofmiddle-east-problems/ [accessed 4 May 2017].

Lecours, A., 2000. Theorizing cultural identities: historical institutionalism as a challenge to the culturalists. Canadian Journal of Political Science, 33 (3), 499-522.

Loeb, V., 1998. Congress stokes visions of war to oust Saddam. The Washington Post, 20 October [online edn.]. Available from: https://www.washingtonpost.com/archive/politics/1998/10/20/congress-stokes-visions-ofwar-to-oust-saddam/ac989d85-7d92-4e65-bfa9-5b54b809e844/?utm term=.e2d2e440dbc1 [accessed 4 May 2017].

Long, A., 2008. The Anbar awakening. Survival, 50 (2), 67-91.

MacDonald, P., 2014. Networks of domination: the social foundations of peripheral conquest in international politics. Oxford: Oxford University Press.

al-Marashi, I., 2007. The dynamics of Iraq's media: ethno-sectarian violence, political Islam, public advocacy, and globalization. Cardozo Arts \& Entertainment Law Journal, 25 (5), 95-140.

al-Marashi, I., 2012. Iraqi politics and control of the media. In: B. Rubin, eds. The Middle East: $a$ guide to politics, economics, society and culture vol. I. Armonk NY: ME Sharpe, 256-264.

Markakis, D., 2016. US democracy promotion in the Middle East: the pursuit of hegemony. Abingdon: Routledge. 
Marr, P., 2006. Who are Iraq's new leaders? What do they want? USIP Special Report 160.

Mazzetti, M. and Daragahi, B. 2005. U.S. military covertly pays to run stories in Iraqi press. Los Angeles Times, 30 November [online edn.]. Available from: http://articles.latimes.com/2005/nov/30/world/fg-infowar30 [accessed 4 May 2017].

Ministry of Planning, 2012. Millennium Development Goals monitoring indicators at governorates level. Baghdad: Central Statistical Organization.

Morrow, J., 2005. Iraq's constitutional process ii: an opportunity lost. Washington DC: USIP.

Mowle, T., 2006. Iraq's militia problem. Survival, 48 (3), 41-58.

Mueller, J., 2000. The banality of 'ethnic war'. International Security, 25 (1), 42-70.

Murray, D., 2014. Iran, Saudi Arabia, and the Middle East's 30 Years War. The Spectator, 25 January [online edn.]. Available from: http://www.spectator.co.uk/features/9122371/armageddon-awaits/ [accessed 4 May 2017].

Muttitt, G., 2012. Fuel on the fire: oil and politics in occupied Iraq. London: Vintage Books.

Nasr, V., 2006. The Shia revival: how conflicts within Islam will shape the future. New York: W. W. Norton.

Niva, S. 2008. Walling off Iraq: Israel's imprint on US counterinsurgency doctrine. Middle East Policy, 15 (3), 67-79.

Nott, A., 2017. Investigating organised crime and war crimes: a personal account of a senior detective in Kosovo, Iraq and beyond. Barnsley: Pen and Sword Books.

O'Hanlon, M. E. and Campbell, J. H., 2008. Iraq index: tracking variables of reconstruction \& security in post-Saddam Iraq. Washington DC: Brookings Institution.

Page | 32 
Otterman, S., 2005. Iraq: debaathfication. Council on Foreign Relations, 22 February [online edn.]. Available from: https://www.cfr.org/backgrounder/iraq-debaathification [accessed 4 May 2017].

Parker, N. and Salman, R., 2013. Notes from the underground: the rise of Nouri al-Maliki and the new Islamists. World Policy Journal, 30 (1), 63-76.

Pfiffner, J. P., 2010. US blunders in Iraq: De-Baathification and disbanding the army. Intelligence and National Security, 25 (1), 76-85.

Platteau, J-P., 2017. Islam instrumentalized: religion and politics in historical perspective. Cambridge: Cambridge University Press.

Price, M., 2007. Foreword: Iraq and the making of state media policy. Cardozo Arts \& Entertainment Law Journal, 25 (5), 5-21.

Rathmell, A., Oliker, O., Kelly, T. K., Brannan, D. and Crane, K., 2005. Developing Iraq's security sector the Coalition Provisional Authority's experience. Santa Monica CA: Rand.

al-Rawi, A. K., 2012. Media practice in Iraq. Basingstoke: Palgrave Macmillan.

al-Rawi, A. K., 2013. The US influence in shaping Iraq's sectarian media. The International Communication Gazette, 75 (4), 374-91.

Reilly, R., 2010. Islam and the West: The theology behind the history. Centre for Research into Post-Communist Economies Occasional Paper 15.

Ricks, T. E., 2008. Fiasco: the American military adventure in Iraq. New York: Penguin.

Roberts, J., 2003. Ex-Iraq boss: mistakes were made. CBS News, 30 November [online edn.]. Available from: https://www.cbsnews.com/news/ex-iraq-boss-mistakes-were-made/ [accessed 4 May 2017].

Page | 33 
Rohde, D. 2005-6. "All successful democracies need freedom of speech": American efforts to create a vibrant free press in Iraq and Afghanistan. Joan Shorenstein Center on the Press, Politics and Public Policy Working Paper Series. Harvard University.

Rhode, H., 2012. Hamas: A pawn in the Sunni-Shiite war. Gatestone Institute, 29 November [online edn.]. Available from: https://www.gatestoneinstitute.org/3472/hamas-sunni-shiite [accessed 4 May 2017].

Ridolfo, K., 2012. Iraq: from captive to relatively free media. In: B. Rubin, eds. The Middle East: a guide to politics, economics, society and culture vol. I. Armonk NY: ME Sharpe, 248-255.

Sanchez, R. S., 2008. Wiser in battle. New York: Harper.

Santora, M., 2007. One year later, Golden Mosque is still in ruins. The New York Times, 13 February [online edn.]. Available from: http://www.nytimes.com/2007/02/13/world/middleeast/13samarra.html [accessed 2 July 2017].

Sassoon, J., 2014. Iraq's political economy post 2003: From transition to corruption. International Journal of Contemporary Iraqi Studies, 10 (1 \& 2) 17-33.

Schwartz, S., 2008. War without end: the Iraq war in context. Chicago: Haymarket Books.

Shils, E., 1957. Primordial, personal, sacred, and civil ties. British Journal of Sociology, 8 (2), 130-145.

Smith, B., Brook-Holland, L. and Page, R., 2014. Islamic state of Iraq and the Levant (ISIS) and the takeover of Mosul. House of Commons Library, 20 June [online edn.]. Available from: http://researchbriefings.files.parliament.uk/documents/SN06915/SN06915.pdf [accessed 4 May 2017].

Solomon, L. D., 2007. Paul D. Wolfowitz: visionary intellectual, policymaker, and strategist. Westport CT: 
Praeger.

Stan, C-I. and Cepoi, E., 2014. Challenges of Iraqi intelligence in Post-Saddam era. Paper presented at the Academia Fortelor Aeriene Conference, Brasov, 22-24 May.

Stavridis, J., 2015. Syrian ghosts. Foreign Policy, 6 November [online edn.]. Available from: http:// foreignpolicy.com/2015/11/06/lessons-from-the-balkans-for-

syria/?utm content $=$ buffer8ab7b\&utm medium $=$ social\&utm source $=$ twitter.com\&utm campai gn=buffer [accessed 4 May 2017].

Steele, J., 2008. Defeat: why they lost Iraq. London: I. B. Tauris.

Stevens, D., 2004. For the Iraqis interviewed, daily life is better today. The New York Times, 29 October [online edn.]. Available from: http://www.nytimes.com/2004/10/29/movies/for-theiraqis-interviewed-daily-life-is-better-today.html [accessed 4 May 2017].

Sullivan, M., 2013. Maliki's authoritarian regime. Middle East Security Report 10. Institute for the Study of War: Washington DC.

Talmon, S., 2013. The occupation of Iraq vol. II: the official documents of the Coalition Provision Authority and the Iraqi Governing Council. Portland OR: Hart Publishing.

Tavernise, S., 2006. District by district, Shiites make Baghdad their own. The New York Times, 23 December [online edn.]. Available from: http://www.nytimes.com/2006/12/23/world/middleeast/23shiites.html?mcubz=2 [accessed 2 July 2017].

Tenet, G., 2007. At the center of the storm: my years at the CIA. New York: HarperCollins.

Thompson, M., 2015. How disbanding the Iraqi army fueled ISIS. Time, 28 May [online edn.]. Available from: http://time.com/3900753/isis-iraq-syria-army-united-states-military/ [accessed 4 May 2017].

Page | 35 
Ucko, D., 2008. Militias, tribes and insurgents: the challenge of political reintegration in Iraq. Conflict, Security \& Development, 8 (3), 341-372.

UNAMI, 2006. Human Rights Report (1 July- 31 August). Baghdad.

United States Department of Defense, 2002. White paper: Rapid Reaction Media Team Concept. National Security Archive. Available from: www.gwu.edu/ $\sim$ nsarchive2.gwu.edu/NSAEBB/NSAEBB219/iraq_media 01.pdf $[$ accessed 4 May 2017].

United States Senate Committee on Armed Services Hearing, 2007. Briefing on the Department of Defense Inspector General's Report on the activities of the Office of Special Plans prior to the war in Iraq. Washington: US Government Printing Office.

Vallely, P., 2014. The vicious schism between Sunni and Shia has been poisoning Islam for 1,400 years - and it's getting worse. The Independent, 19 February [online edn.]. Available from: http://www.independent.co.uk/news/world/middle-east/the-vicious-schism-between-sunniand-shia-has-been-poisoning-islam-for-1400-years-and-its-getting-9139525.html [accessed 4 May 2017].

Visser, R., 2007-8. The Western imposition of sectarianism on Iraqi politics. The Arab Studies Journal, 15 (2), 83-99.

Visser, R., 2009. Biden, US policy in Iraq and the concept of mubasasa. Historiae, 6 July [online edn.]. Available from: http://www.historiae.org/muhasasa.asp [accessed 4 May 2017].

Visser, R., 2010. Iraq moves backward. Middle East Report, 255 (summer), 2-7.

Weiss, M., 2010. In the shadow of sectarianism: law, Shi'ism, and the making of modern Lebanon. Cambridge MA: Harvard University Press. 
Whitaker, B., 2003. Friends of the family. The Guardian, 24 September [online edn.]. Available from: https://www.theguardian.com/world/2003/sep/24/worlddispatch.usa [accessed 4 May 2017].

Whitaker, B. and Howard, M., 2004. Wanted for murder of finance official. The Guardian, 10 August [online edn.]. Available from: https://www.theguardian.com/world/2004/aug/10/iraq.brianwhitaker1 [accessed 4 May 2017].

Whyte, D., 2007. The Crimes of neo-liberal rule in occupied Iraq. The British Journal of Criminology, 47 (2), 177-195.

Wong, E., 2006. To stay alive, Iraqis change their names. The New York Times, 6 September [online edn.]. Available from: http://www.nytimes.com/2006/09/06/world/middleeast/06identity.html?pagewanted=all [accessed 2 July 2017].

Yousif, B., 2006. Coalition economic policies in Iraq: motivations and outcomes. Third World Quarterly, 27 (3), 491-505.

Yousif, B., 2007. Economic restructuring in Iraq: intended and unintended consequences. Journal of Economic Issues, 41 (1), 43-60.

Yousif, B., 2010. The political economy of sectarianism in Iraq, International Journal of Contemporary Iraqi Studies, 4 (3), 357-67. 